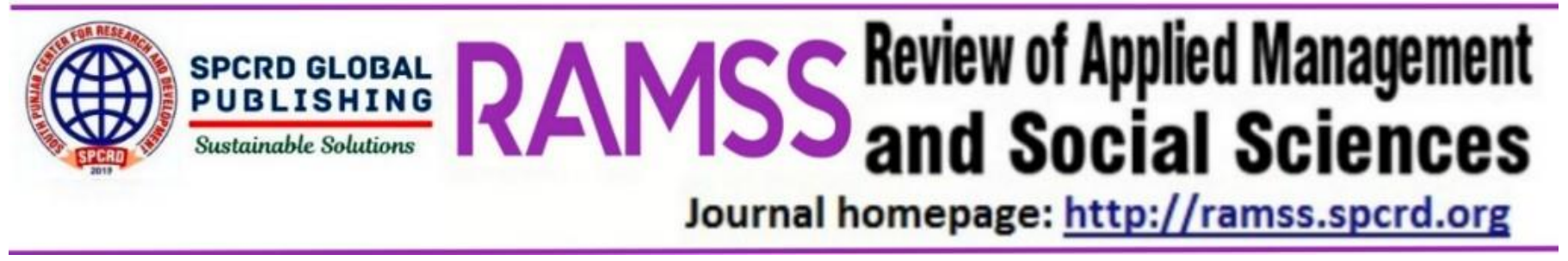

\title{
Volatility of Islamic Stock Markets and Developed Stock Markets of G6 Countries
}

\author{
${ }^{a}$ Muhammad Mansoor, ${ }^{b}$ Hina Ismail, 'Shahzad Akhtar, ${ }^{\mathrm{d}}$ Haroon Hussain \\ aLecturer, University of Mianwali, Department of Commerce: mansoor_uos@yahoo.com \\ becturer, National University of Modern Languages, Multan Campus, Pakistan: hina.ismail@numl.edu.p \\ 'Lecturer, Institute of Management Science BZU, Multan, Pakistan: drshahzadakhtar@bzu.edu.pk \\ dAssistant Professor, Noon Business School, UOS haroon.hussain@uos.edu.pk
}

Corresponding author's email address: mansoor_uos@yahoo.ocm

\begin{tabular}{|c|c|}
\hline ARTICLE DETAILS & ABSTRACT \\
\hline $\begin{array}{l}\text { History: } \\
\text { Accepted: 11June } 2019 \\
\text { Available: online } 30 \text { June2019 }\end{array}$ & \multirow{3}{*}{$\begin{array}{l}\text { The objective of this to measure and compare Volatility of Islamic stock } \\
\text { markets with equity markets of developed(G6) countries by taking daily } \\
\text { values for period 2000-2016. The technique of Augmented fuller test (ADF), } \\
\text { Heteroscedasticity test, ARCH (1,o), GARCH }(1,1) \text {, TARCH and E-GARCH are } \\
\text { applied. The results show Islamic stock markets shows positive returns as } \\
\text { compare to previous day return but the Developed equity markets (G6) } \\
\text { shows negative returns as compare to previous day return expect span and } \\
\text { Poland equity market. The study explored that in all the stock markets the } \\
\text { previous day volatility transfers in the next day volatility and there are } \\
\text { many other factors affect the stock market volatility. The study is helpful in } \\
\text { building stock portfolio for individual or institutional investor and for policy } \\
\text { maker in decision making. }\end{array}$} \\
\hline $\begin{array}{l}\text { Keywords: } \\
\text { Firm, Islamic Markets Volatility, } \\
\text { Developed (G6 countries) } \\
\text { Markets Volatility, ARCH, } \\
\text { GARCH, EGARCH, }\end{array}$ & \\
\hline $\begin{array}{l}\text { JEL Classification: } \\
\underline{D 2 O, D 21, D 29}\end{array}$ & \\
\hline DOI: $10.47067 /$ ramss.v2i1.10 & $\begin{array}{r}\text { (C) } 2019 \text { The authors. Published by SPCRD Ltd. This is an open access article } \\
\text { under the Creative Commons Attribution-NonCommercial } 4.0\end{array}$ \\
\hline
\end{tabular}

\section{Introduction}

Commonly it is considered that only strong economy markets can lead toward higher return with lower risks, while weak economy markets would not give fruitful return to investors. There are many stock markets in the world having different nature, some shows the higher volatility style or behavior and other show contrast style. The Islamic markets are distinguished from other equity markets due to the existence of Islamic organizations who following the Sharia based rules in day to day business. so, the Islamic countries markets and developed countries markets have different volatility level one of the major cause the lot of Islamic sharia based organization exist in Islamic country equity markets. volatility is a risk about investors security. Before investment in stocks investors and decision makers have certain level of risk about the securities at which they want to invest their asset. Speculators always try to invest their funds and asset in those markets which have higher value of beta, to get the fruitful return. For investor point of view the portfolio should be minimum risk and 
maximum return. When volatility of Islamic and G6 markets is lower, situation is ripe for stock prices to rise in value, lead to increases the return in an investment portfolio (Yusof \& Majid 2013). The investors who make investment in Islamic countries markets with developed countries markets has aim to evade or hedge the risk of securities. Changes in security prices of Islamic and developed countries markets influence the behavior of investors regarding investment. Research tenacity is to quota the volatility of Islamic and developed regions markets and analyze stock volatile risk, which Islamic and developed counties markets faces due to different economic and political situation.

The word "Volatility" means ability to change rapidly and unpredictably. Stock market volatility means the behavior or responses of stock markets. The previous studies explore the volatility in stock return of different markets during previous lags among Pakistan, India, japan and Hong Kong(Subhani 2009) but focus on interest rate. Movement of stock market prices can be predicted on focusing of changing primary and secondary trends (DOW theory 2003). Stock market prices moves in cyclic manner; market continuously unfold in the form of waves (Elliot wave theory 2004). sometimes stock markets prices move up and sometime move down either in the form of cyclic or crest \& trough.

No empirical work has been done yet on volatility of Islamic countries markets with developed markets. Both type of markets showing some nature of volatility. The goal of this study is to analyze that which markets are more volatile (Islamic countries markets or developed countries markets). The current study is attempting to find the stock return of different markets during previous lags by focusing on volatility of Islamic countries markets with developed markets. All these equity markets have different economic environment. This will help the investors or financial institutions to solve the problem of investing funds \& asset in stock markets regarding stock return. Research purpose is to measure the volatility of Islamic and developed counties markets and analyze stock volatile risk, which Islamic and developed counties markets faces due to different economic and political situation.

\section{Litrature Review:}

Chukwuogor and Feridun (2007) measured and compared the stock returns volatility of emerging stock markets and developed stock markets. Secondary data during the 1947 to 2004 was collected. ARCH and GARCH technique were used for data analysis purpose. They found that emerging markets are more volatile and offer more return than developed economies markets.

Albaity (2011) examined the effect of monetary policy instrument on Islamic market stock returns by collecting data for period 1992-2000. The study used the GARCH model to check the volatility of index (KLSI) and DJIMI. The result reveals that model M1, M3, inflation rate and GDP influencing KLCI volatility. Moreover, they concluded that conventional stock market affected by interest rate, while this effect is not observed on volatility of Islamic markets.

Volatility of Islamic and G6 market affect the future cash flow and the study of both markets is compulsory before making any investment decision. Aksoy et al., (2011) studied the association ship among Turkey, Egypt and Israel stocks exchanges. Data was collected during the period of 2002 to 2010 on weekly basis. Study used Co integration, Engle Granger test and GARCH model for data analysis purpose. They found that co-integration and volatility exited among these countries market. These markets provide diversification opportunities to international investors.

Ergun and Nor (2010) examined the volatility existence and dynamic relationship between Turkish stock market and USA stock market with reference to Turkey's association to EU. For study 
purpose they choose Istanbul Stock Exchange from Turkey and NASDAQ from USA. Daily data for the period of 1988 to 2008 was collected and Bi-variate co integration, ECM and CGARCH techniques were employed for analysis purpose. Result showed that dynamic linkage existed between Turkish stock market and American stock market. Study also found that significant volatility run from USA stock market to Turkey stock market after the entrance of Turkey in Custom union Agreement with European Union. Alper and Yilmaz (2004) used Generalized Autoregressive conditional Heteroskedasticity $(\mathrm{GARCH})$ to measure the stock return volatility infection from financial centers and emerging markets to the Istanbul stock market. Funding indicated existence of volatility contagion from emerging market and financial centers to Turkish stock exchange market.

Ahmed and Suliman (2011) investigated the stock returns volatility in Khartoum Stock Exchange of Sudan. For research purpose data was collected during 2005-2010. GARCH model was used to measure the stock return volatility. It was found that during sample period high volatility of index returns exists in Khartoum stock market of Sudan. Emenike (2011) examined the behavior of stock return volatility in Nigerian by using GARCH model. Data collected on monthly basis during the period of 1999 - 2008 about All share Induces of Nigeria Stock Exchange. The GARCH model results showed that volatility clustering is existed in NSE stock returns series. Parvaresh and Bavaghar (2012) found that GARCH Model had a power to forecast stock returns volatility in Tehran Stock Market. Wu et al.,(2004) examined the volatility of Chinese Stock markets by using series of ARCH models. Two different Chinese stock markets are chosen and different ARCH models are applied on these markets. They found that no volatility transmission prevailing between Shenzhen stock market and Shanghai stock market in China.

H1: The stock return volatility of current period predicts on previous stock return volatility.

H2: Islamic equity markets are less volatile than developed equity markets.

\section{Methadology}

This study focus on daily stock prices indexes of Islamic markets and developed market for the period $1^{\text {st }}$ week of January-200o to last week of March-2016.The data was collected from the sources of yahoo. Finance and investing.com. This study applied ADF(Augmented Dickey fuller test), Heteroscedasticity test, ARCH, GARCH, TARCH and E-GARCH methods are used to measures volatility of selected markets. ARCH test tells us about nature of volatility, that how periods of low volatility are followed by periods of high volatility when we deal stock markets. While GARCH model used to forecast the return of current investments and E-GARCH gives the information about size and bad or good news effect.

\section{Results}

Table 1:Unit root (Augmented Dicky fuller test)

\begin{tabular}{|c|c|c|c|c|c|c|c|c|c|c|}
\hline & France & UK & Italy & Spain & Indo & PAK & Oman & POL & Tur & Ger \\
\hline $\mathrm{ADF}$ & - & - & - & -30.242 & -56.353 & - & - & - & - & - \\
\hline $\begin{array}{l}\text { level } \\
\text { T- } \\
\text { stat }\end{array}$ & 31.792 & 31.383 & 66.355 & & & $55 \cdot 554$ & $13 \cdot 302$ & 35.985 & 64.567 & 65.37 \\
\hline
\end{tabular}

\section{Critical Values}

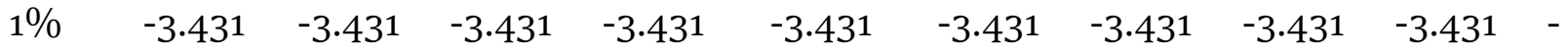


level

$5 \%$

$-2.862$

$-2.862-2.862$

$-2.862$

$-2.862$

$-2.862$

$-2.86$

$-2.862$

$-2.862$

level

$-2.567 \quad-2.567 \quad-2.567 \quad-2.567$

$-2.567$

$-2.567$

$-2.567$

$-2.567$

$-2.567$

level

To check the volatility of equity markets through the ARCH family its necessary that the Data should be stationary to fulfill this condition to check the unit root ADF test applied. The results indicate that all the stock markets returns are stationary at level.

Table 2 (Heteroscedasticity Test)

\begin{tabular}{lllcll}
\hline States & F-stat & P.F(1,3867) & $r^{2}$ & Chi-^2 (1) & Result \\
\hline Turkey & 395.2543 & 0.000 & 361.0344 & 0.000 & Significant \\
Pakistan & 344.4611 & 0.000 & 316.4507 & 0.000 & Significant \\
Indonesia & 130.8135 & 0.000 & 126.6599 & 0.000 & Significant \\
Oman & 192.9044 & 0.000 & 183.6537 & 0.000 & Significant \\
France & 153.426 & 0.000 & 148.0185 & 0.000 & Significant \\
Germany & 174.33 & 0.000 & 163.22 & 0.000 & Significant \\
Spain & 2.512781 & 0.1133 & 2.511384 & 0.113 & Insignificant \\
$\begin{array}{l}\text { Italy } \\
\text { United }\end{array}$ & 160.5918 & 0.000 & 154.6917 & 0.000 & Significant \\
Kingdom & 188.6912 & 0.000 & 178.5913 & 0.000 & Significant \\
Poland & 2.128501 & 0.1448 & 2.128291 & 0.1446 & Insignificant \\
\hline
\end{tabular}

\section{Residuals Graphs:}

France

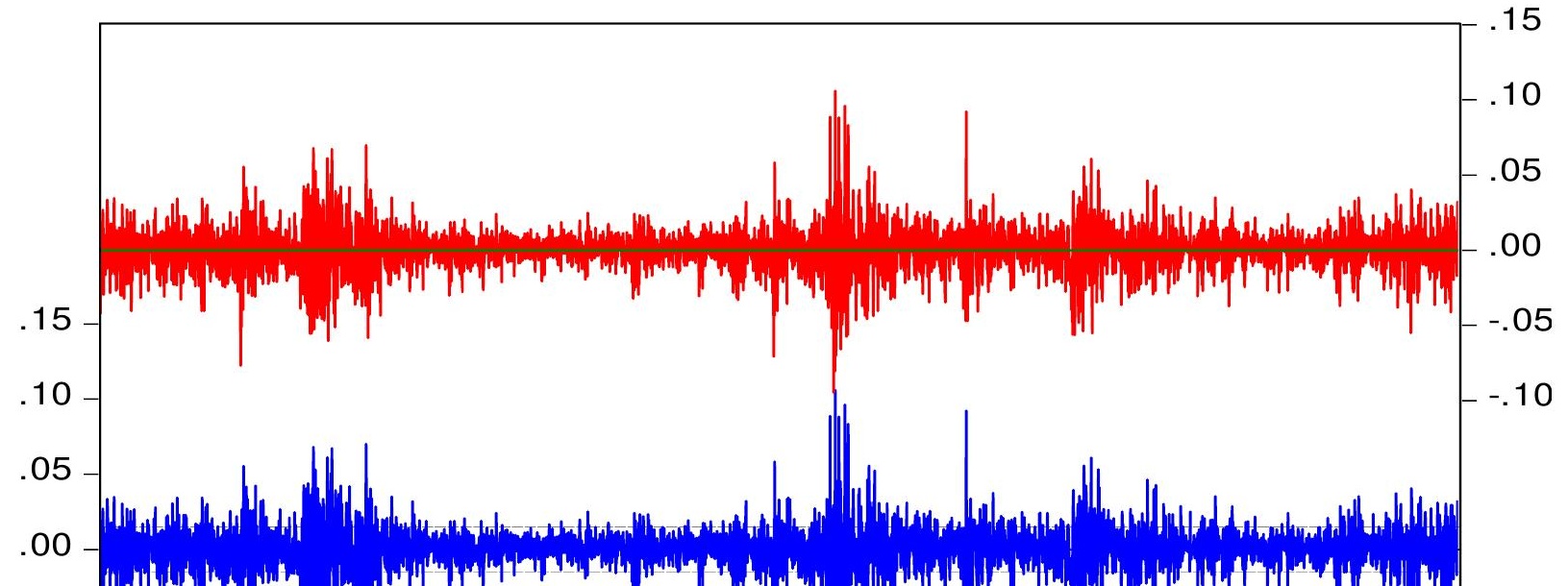




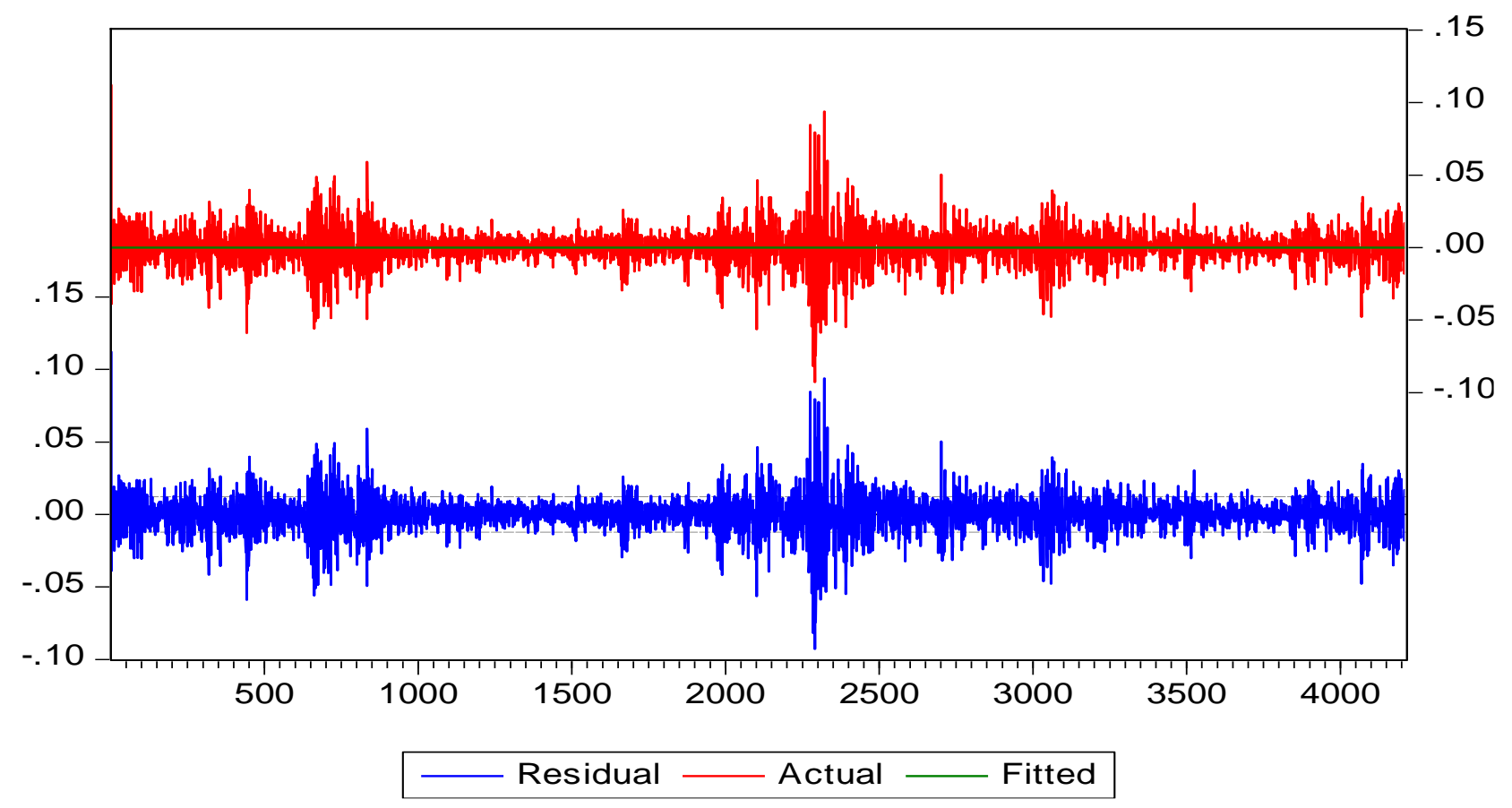

Italy

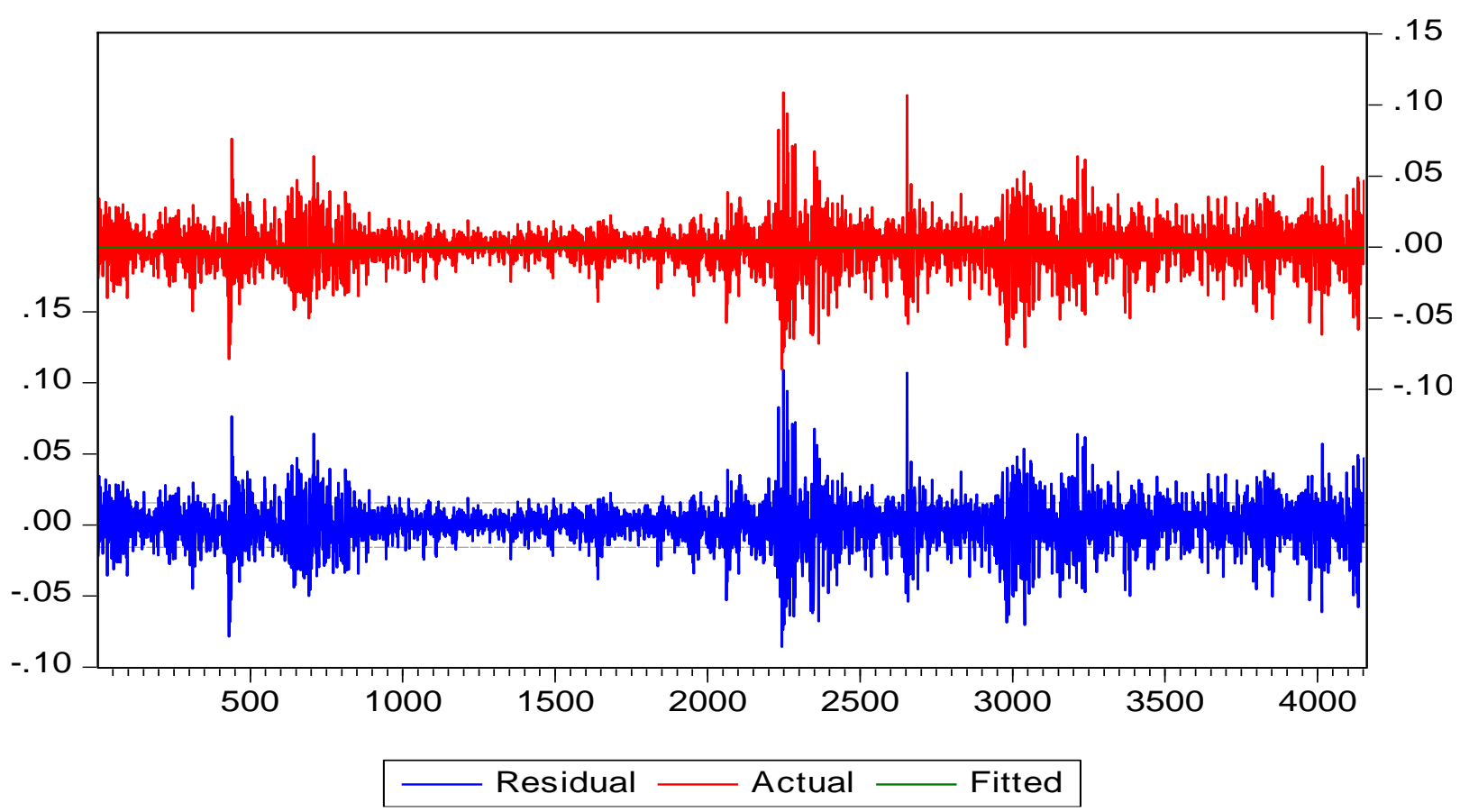


Spain

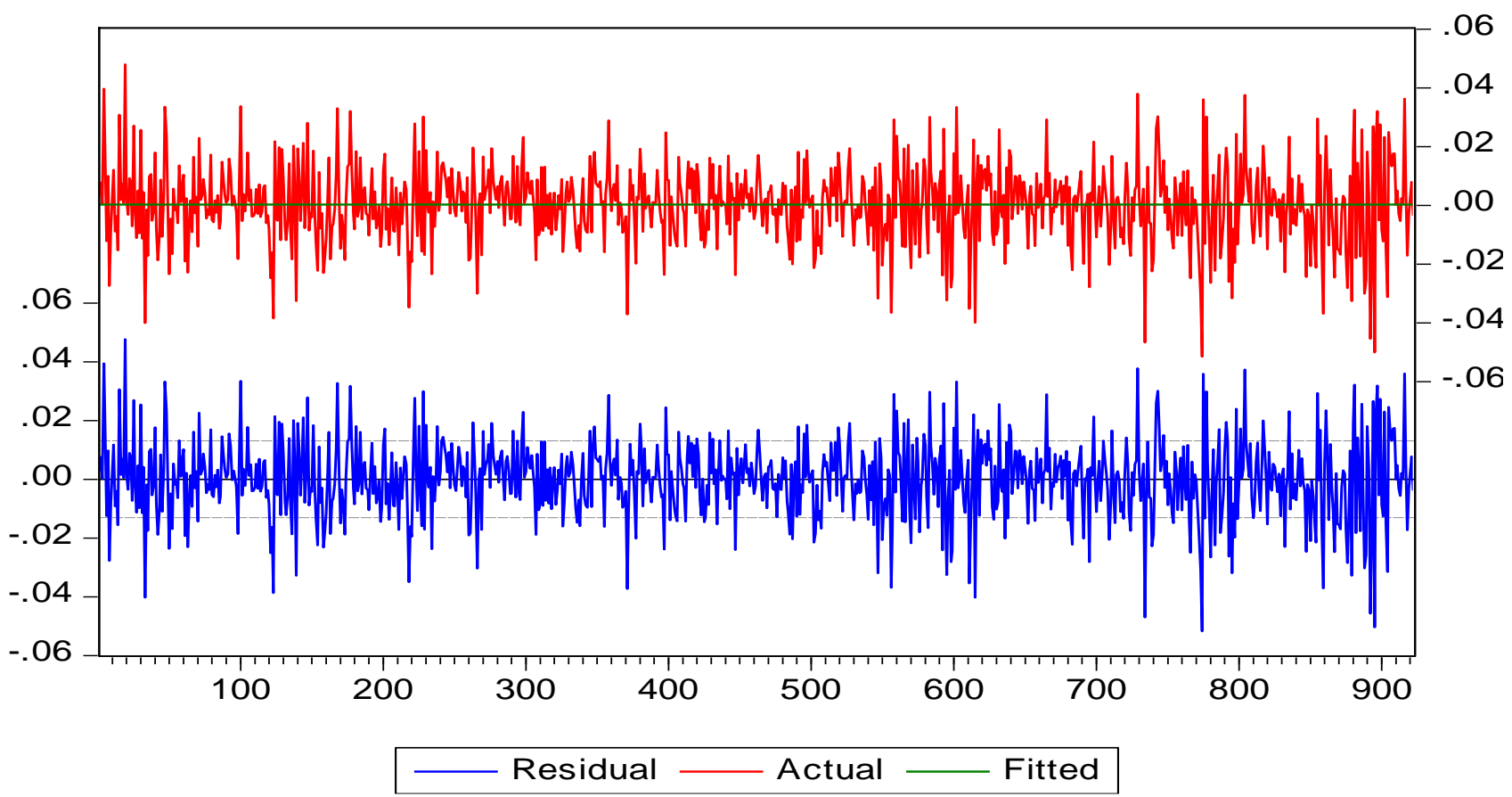

Indonesia

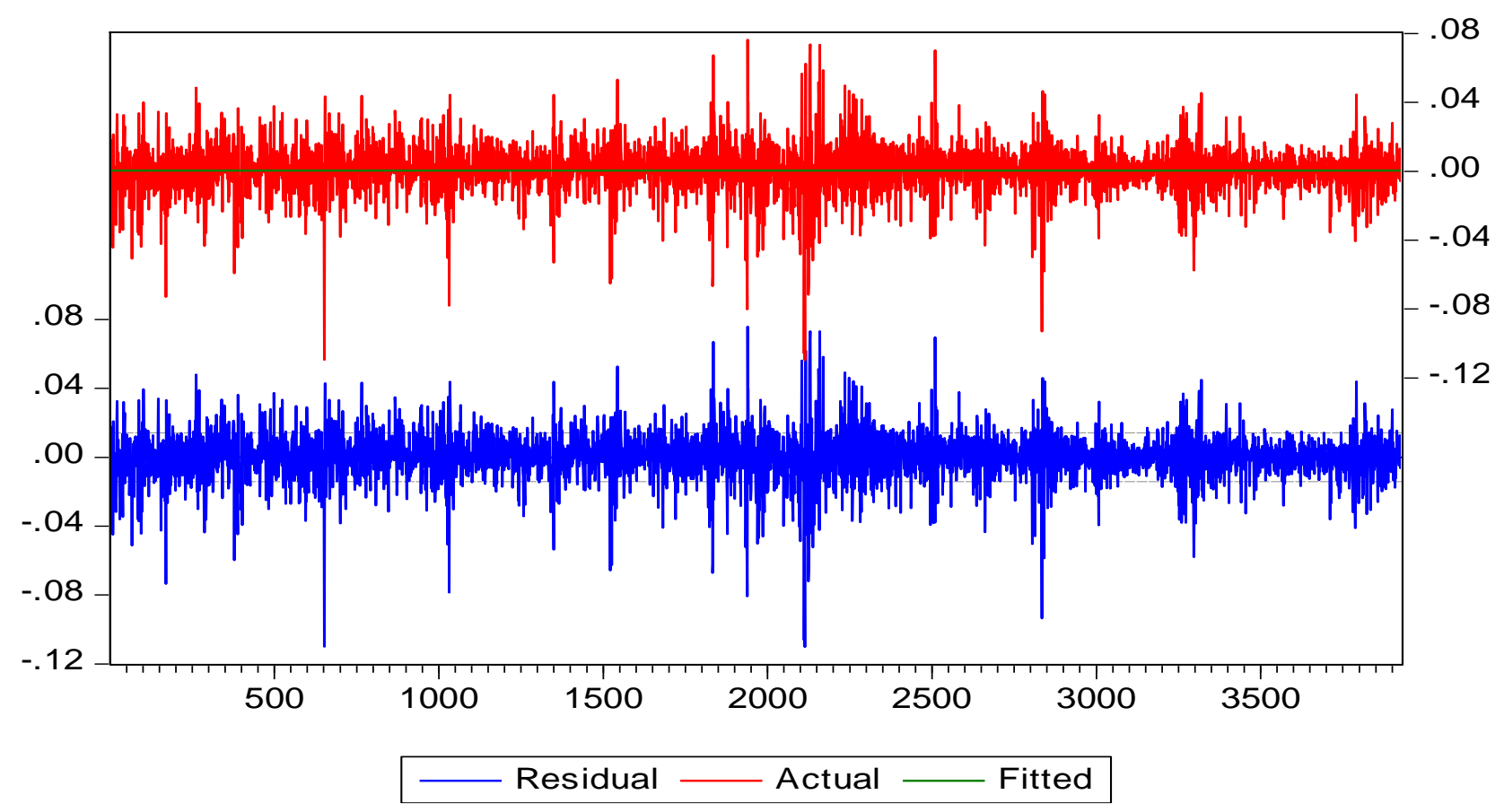




\section{Pakistan}

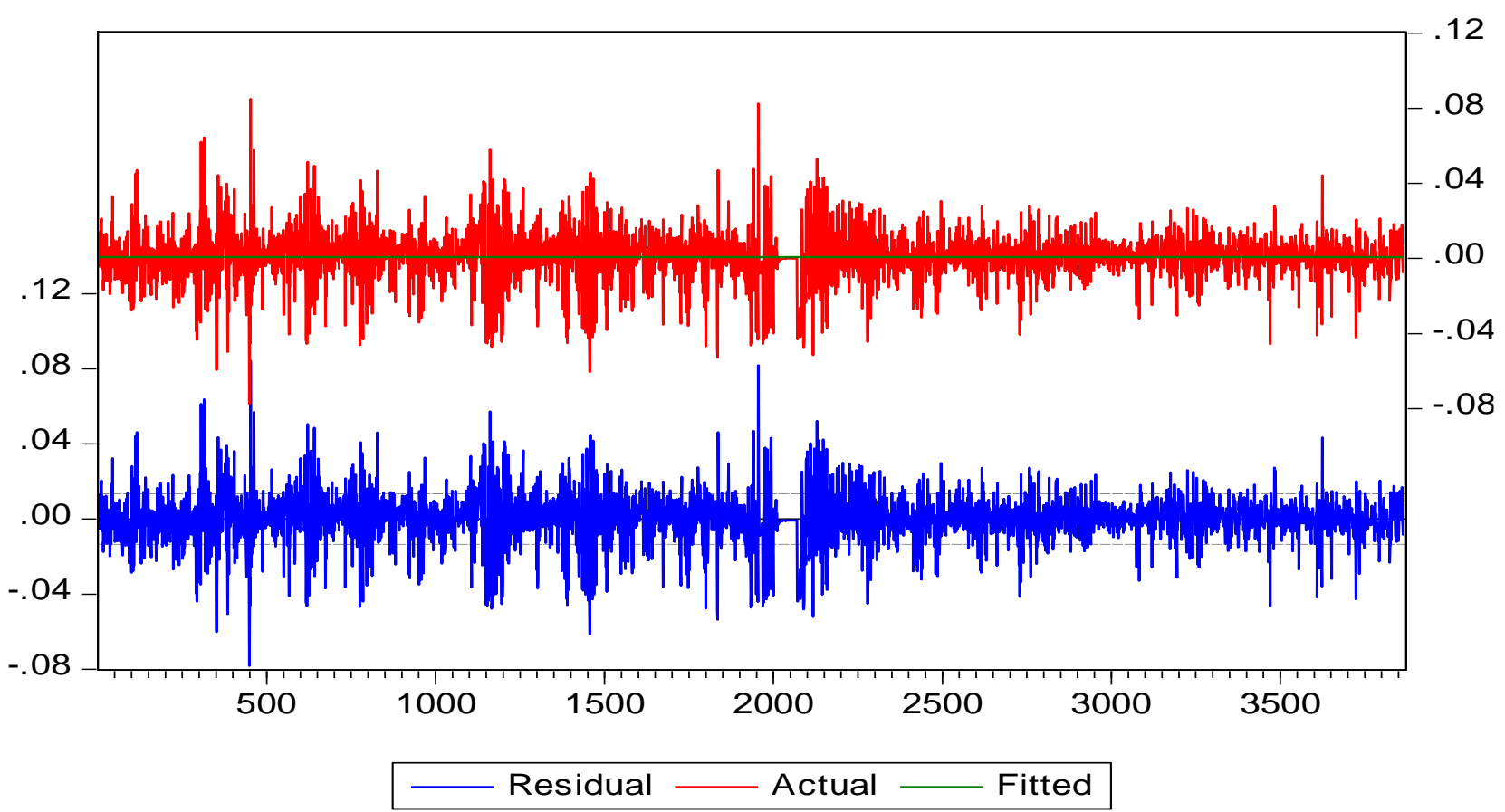

\section{Oman}

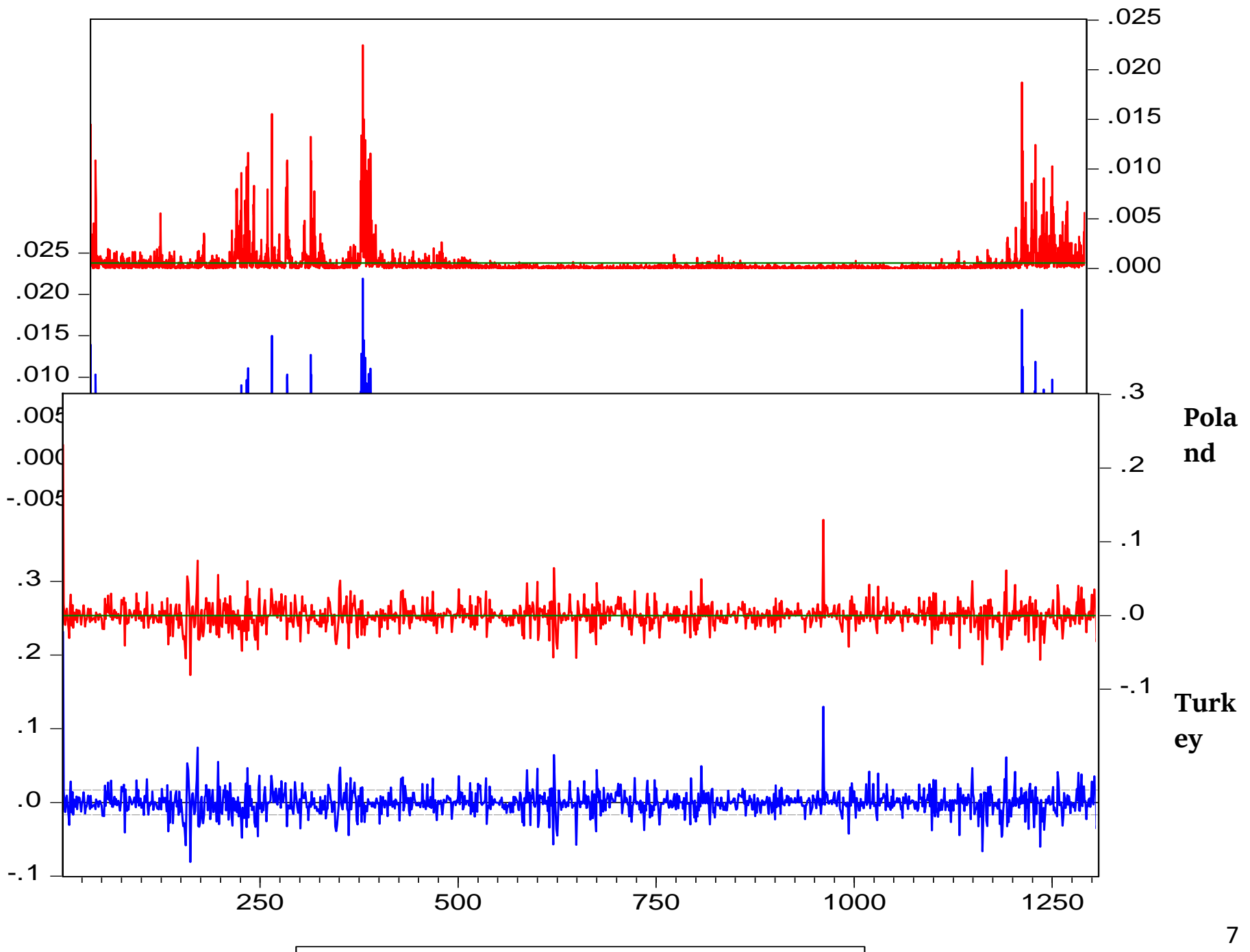




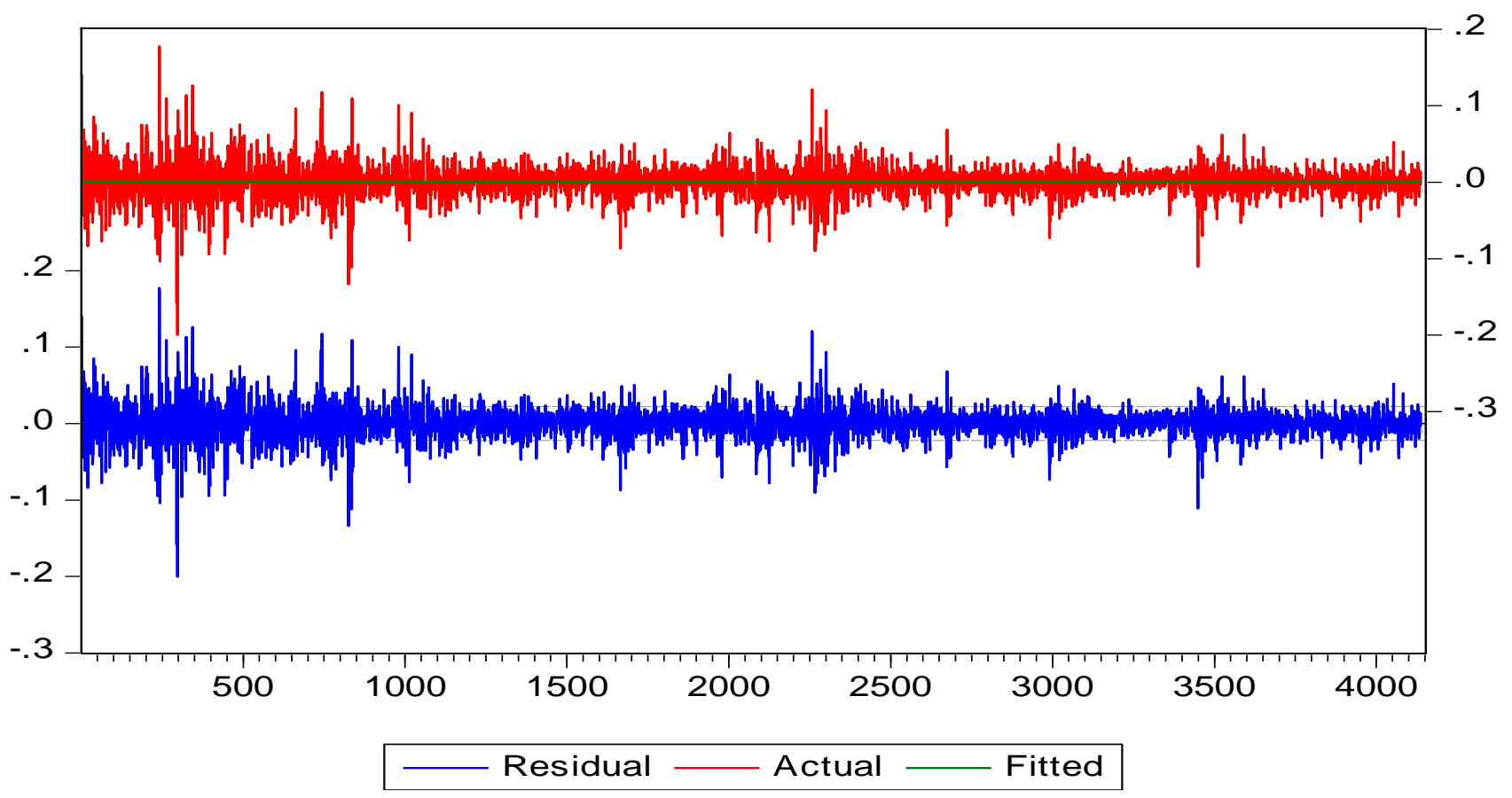

\section{Germany}

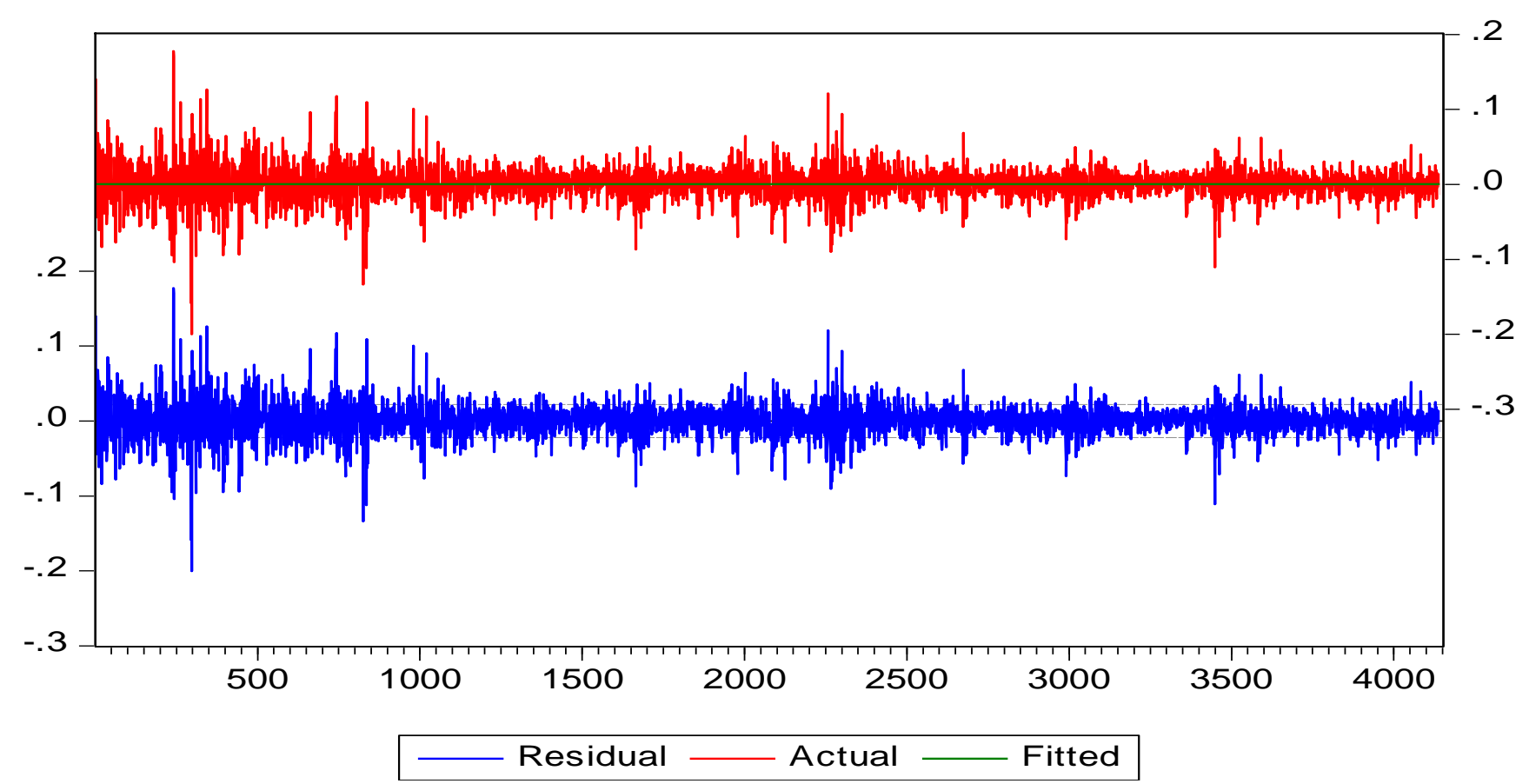

The Residuals Graphs also verified that the periods of low volatility is followed by periods of low volatility for prolonged period. While the periods of high volatility is followed by periods of high volatility for prolonged period. This pattern confirms that of this study can apply ARCH family for the on the data. 
For all markets, the data result represents coefficient of Heteroscedasticity are significant, except Spain and Poland. Results of heteroscedasticity confirm that $\mathrm{F}$ value is 395 and $\mathrm{p}$ value is less than 0.05 means model is significant. This reflect model is fit to explain volatility of Islamic and G6 stock market.

Table 3: ARCH (Autoregressive conditional heteroskedasticity Test)

\begin{tabular}{|c|c|c|c|c|c|c|}
\hline & $\mathrm{ME}$ & & & VE & & \\
\hline & Var & Coef. & $\mathrm{P}$ & Var & Coef. & $\mathrm{P}$ \\
\hline Turkey & $\operatorname{BIST}(-1)$ & 0.05053 & 0.0061 & $\mathrm{RSD}(-1)$ & 0.000352 & 0.002616 \\
\hline Pakistan & $\operatorname{KSE}(-1)$ & 0.092316 & 0.005 & $\operatorname{RSD}(-1)$ & 0.44368 & 0.0078 \\
\hline Indonesia & $\mathrm{JKSE}(-1)$ & 0.063044 & 0.03 & $\operatorname{RSD}(-1)$ & 0.324728 & 0.005 \\
\hline Oman & $\operatorname{MSM} 30(-1)$ & 0.662313 & 0.04 & $\operatorname{RSD}(-1)$ & 5.231318 & 0.0036 \\
\hline France & $\mathrm{CAC}_{40}(-1)$ & -0.03043 & 0.0001 & $\operatorname{RSD}(-1)$ & 0.255074 & 0.0034 \\
\hline Germany & $\operatorname{DAX}(-1)$ & 0.00254 & 0.0272 & $\operatorname{RSD}(-1)$ & 0.293061 & 0.0084 \\
\hline Spain & $\operatorname{IBEX} 35(-1)$ & 0.010906 & 0.0081 & $\operatorname{RSD}(-1)$ & 0.089133 & 0.01 \\
\hline Italy & $\begin{array}{l}\text { FTSE MIB(- } \\
\text { 1) }\end{array}$ & -0.05544 & 0.00 & $\operatorname{RSD}(-1)$ & 0.277024 & 0.00 \\
\hline $\begin{array}{l}\text { United } \\
\text { Kingdom }\end{array}$ & $\begin{array}{l}\text { FTSE10o(- } \\
\text { 1) }\end{array}$ & -0.06851 & 0.00 & $\operatorname{RSD}(-1)$ & 0.407659 & 0.00 \\
\hline Poland & WIG $(-1)$ & 0.00207526 & 0.0289 & $\mathrm{RSD}(-1)$ & 0.379285 & 0.007 \\
\hline
\end{tabular}

In the Mean equation of $\mathrm{ARCH}$ the positive value of coefficient of explain that the today returns of BIST (-1) 5.05\%, KSE (-1) 9.235\%, JKSE(-1) 6.30\%, MSM30(-1) 66.23\%, DAX(-1) 0.25\%, IBEX35(-1) $1.09 \%$ and WIG(-1) $0.20 \%$ is higher than the previous day return respectively. While the negative value of coefficient of CAC4O(-1) 3.04\%, FTSE MIB(-1) 5.54\% and FTSE 100(-1) $6.85 \%$ is less than the previous day return.

In variance equation of $\mathrm{ARCH}(1)$, the P value of RESID (-1) of BIST (-1) is $0.02 \%, \mathrm{KSE}(-1)$ 0.07\%, JKSE(-1) 0.05\%, MSM30(-1) 0.03\%, DAX(-1) 0.84\%, IBEX35(-1) $0.1 \%$ and WIG(-1) $0.07 \%$, CAC40(-1) $0.34 \%$, FTSEMIB(-1) $0.00 \%$ and FTSE $100(-1) 0.00 \%$ is significant which shows that today's volatility can be explained on the basis of past price behavior. Further the value of coefficient of residual is positive which shows that BIST $(-1)$ is $0.03 \%$, KSE $(-1) 44.36 \%$, JKSE(-1) 32.47\%, DAX(-1) 29.30\%, IBEX35(-1) 8.91\% and WIG(-1) 37.92\%, CAC40(-1) 25.50\%, FTSEMIB(-1) 27.70\% and FTSE $100(-1) 40.76 \%$ today volatility is high as compare to previous day volatility..

Table: 4 GARCH ( Generalized autoregressive conditional heteroscedasticity Test)

$\begin{array}{llll}\text { Country } & \text { Index } & \text { Variable } & \text { Coff }\end{array}$




\begin{tabular}{lllll}
\hline Turkey & BIST & GARCH (-1) & 0.90271 & 0.0000 \\
Pakistan & KSE & GARCH (-1) & 0.784363 & 0.0000 \\
Indonesia & JKSE & GARCH (-1) & 0.84176 & 0.0000 \\
Oman & MSM30 & GARCH (-1) & 0.911238 & 0.0000 \\
France & CAC40 & GARCH (-1) & 0.901624 & 0.0000 \\
Germany & DAX & GARCH (-1) & 0.899111 & 0.0000 \\
Spain & IBEX35 & GARCH (-1) & 0.895964 & 0.0000 \\
Italy & FTSE MIB & GARCH (-1) & 0.911216 & 0.0000 \\
UK & FTSE100 & GARCH (-1) & 0.879403 & 0.0000 \\
Poland & WIG & GARCH (-1) & 0.442037 & 0.0000 \\
\hline
\end{tabular}

The P-value of GARCH $(-1)$ in all the stock markets are significant which indicates that today's volatility is affected due to the previous day volatility. Further the coefficient of GARCH $(-1)$ is positive for all the stock market indices which shows that for BSIT(Turkey)90.27\%,KSE(Pakistan) 78.43\%, JKSE(Indonesia) 84.17\%,MSM30 (Oman) 91.12\%,CAC40(France) 90.16\%, DAX(Germany) 89.91\%,IBEX35(Spain) 89.59\%,FTSE MIB(Italy) 91.12\%, FTSE10o(UK) $87.94 \%$ and WIG(Poland) $44.20 \%$ last day volatility transfer in next day respectively in the stock market returns.

Table:5 TARCH (Threshold Autoregressive conditional heteroskedasticity Test)

\begin{tabular}{lllll}
\hline Country & Index & Variable & Coff & P. \\
\hline Turkey & BIST & $\begin{array}{l}\text { RESID }(- \\
1)^{\wedge} 2^{*}(\operatorname{RESID}(-1)<0)\end{array}$ & 0.168008 & 0.1084 \\
& & & \\
& & & \\
Pakistan & KSE & $\begin{array}{l}\text { RESID(- } \\
1)^{\wedge} 2^{*}(\operatorname{RESID}(-1)<0)\end{array}$ & 0.103537 & 0.01 \\
& & & \\
Indonesia & JKSE & $\begin{array}{l}\text { RESID(- } \\
1)^{\wedge} 2^{*}(\operatorname{RESID}(-1)<0)\end{array}$ & 0.112983 & 0 \\
& & & \\
Oman & MSM30 & RESID $(-$ & -0.41254 & 0
\end{tabular}



$1)^{\wedge} 2^{*}(\operatorname{RESID}(-1)<0)$

\begin{tabular}{|c|c|c|c|c|}
\hline France & CAC40 & $\begin{array}{l}\operatorname{RESID}(- \\
1)^{\wedge} 2^{*}(\operatorname{RESID}(-1)<0)\end{array}$ & 0.168008 & $\mathrm{O}$ \\
\hline Germany & DAX & $\begin{array}{l}\operatorname{RESID}(- \\
1)^{\wedge} 2^{*}(\operatorname{RESID}(-1)<0)\end{array}$ & -0.01011 & 0.001 \\
\hline Spain & IBEX35 & $\begin{array}{l}\operatorname{RESID}(- \\
1)^{\wedge} 2^{*}(\operatorname{RESID}(-1)<0)\end{array}$ & 0.180215 & 0.9526 \\
\hline Italy & FTSE MIB & $\begin{array}{l}\operatorname{RESID}(- \\
1)^{\wedge} 2^{*}(\operatorname{RESID}(-1)<0)\end{array}$ & 0.114682 & 0.003 \\
\hline UK & FTSE100 & $\begin{array}{l}\operatorname{RESID}(- \\
1)^{\wedge} 2^{*}(\operatorname{RESID}(-1)<0)\end{array}$ & 0.169848 & 0.0000 \\
\hline Poland & WIG & $\begin{array}{l}\operatorname{RESID}(- \\
1)^{\wedge} 2^{*}(\operatorname{RESID}(-1)<0)\end{array}$ & 0.24596 & 0.0025 \\
\hline
\end{tabular}

Table 5 E-GARCH ( ExponentialGeneralized autoregressive conditional heteroscedasticity Test)

\begin{tabular}{|c|c|c|c|c|c|c|}
\hline & ME & & & VE & & \\
\hline & Coff & $\mathrm{P}$ & Var & Coff & $\mathrm{P}$ & \\
\hline \multirow{4}{*}{ Turkey } & \multirow{4}{*}{ BIST $(-1)$} & \multirow{4}{*}{0.01235} & \multirow{4}{*}{0.4195} & $\mathrm{C}_{3}$ & -0.24308 & \multirow{4}{*}{0.000} \\
\hline & & & & $\mathrm{C}_{4}$ & 0.177352 & \\
\hline & & & & $\mathrm{C}_{5}$ & 0.986133 & \\
\hline & & & & C6 & 0.1093 & \\
\hline \multirow{4}{*}{ Pakistan } & \multirow{4}{*}{$\operatorname{KSE}(-1)$} & \multirow[t]{4}{*}{0.107219} & & $\mathrm{C}_{3}$ & -1.03999 & \multirow{4}{*}{0.000} \\
\hline & & & & $\mathrm{C}_{4}$ & 0.329807 & \\
\hline & & & 0.01 & $\mathrm{C}_{5}$ & -0.10188 & \\
\hline & & & & $\mathrm{C} 6$ & 0.911223 & \\
\hline \multirow{4}{*}{ Indonesia } & \multirow{4}{*}{ JKSE (-1) } & \multirow{4}{*}{0.087187} & & $\mathrm{C}_{3}$ & -0.5198 & \multirow{4}{*}{0.000} \\
\hline & & & & $\mathrm{C}_{4}$ & 0.258321 & \\
\hline & & & 0.000 & $\mathrm{C}_{5}$ & 0.962633 & \\
\hline & & & & $\mathrm{C} 6$ & 0.1456 & \\
\hline \multirow{3}{*}{ Oman } & \multirow{3}{*}{$\operatorname{MSM} 30(-1)$} & 0.257143 & & $\mathrm{C}_{3}$ & -0.25435 & \multirow{3}{*}{0.000} \\
\hline & & & 0.000 & $\mathrm{C}_{4}$ & 0.179865 & \\
\hline & & & & $\mathrm{C}_{5}$ & 0.103305 & \\
\hline
\end{tabular}




\begin{tabular}{|c|c|c|c|c|c|c|}
\hline \multirow{5}{*}{ France } & \multirow{4}{*}{$\mathrm{CAC}_{40}(-1)$} & \multirow{4}{*}{-0.03553} & \multirow{4}{*}{0.0319} & $\mathrm{C} 6$ & \multicolumn{2}{|l|}{0.991951} \\
\hline & & & & $\mathrm{C}_{3}$ & -0.24234 & \\
\hline & & & & $\mathrm{C}_{4}$ & o.089875 & \\
\hline & & & & $\mathrm{C}_{5}$ & -0.13921 & 0.000 \\
\hline & \multirow{5}{*}{$\operatorname{DAX}(-1)$} & \multirow{5}{*}{-0.00665} & & $\mathrm{C} 6$ & 0.980483 & \\
\hline \multirow{4}{*}{ Germany } & & & \multirow{4}{*}{0.6914} & $\mathrm{C}_{3}$ & -0.26941 & \\
\hline & & & & $\mathrm{C}_{4}$ & 0.119166 & \multirow{3}{*}{0.000} \\
\hline & & & & $\mathrm{C}_{5}$ & -0.11918 & \\
\hline & & & & $\mathrm{C} 6$ & 0.97978 & \\
\hline \multirow{4}{*}{ Spain } & \multirow{4}{*}{$\operatorname{IBEX} 35(-1)$} & \multirow{4}{*}{0.028353} & \multirow{4}{*}{0.4318} & $\mathrm{C}_{3}$ & -0.3219 & \multirow{4}{*}{0.1169} \\
\hline & & & & $\mathrm{C}_{4}$ & 0.029621 & \\
\hline & & & & $\mathrm{C}_{5}$ & -0.12041 & \\
\hline & & & & $\mathrm{C} 6$ & 0.966011 & \\
\hline \multirow{4}{*}{ Italy } & \multirow{3}{*}{$\begin{array}{l}\text { FTSE MIB } \\
(-1)\end{array}$} & \multirow{3}{*}{-0.03606} & \multirow{4}{*}{0.0303} & $\mathrm{C}_{3}$ & -0.22553 & \multirow{4}{*}{0.000} \\
\hline & & & & $\mathrm{C}_{4}$ & 0.112316 & \\
\hline & & & & $\mathrm{C}_{5}$ & -0.10135 & \\
\hline & \multirow{5}{*}{$\begin{array}{l}\text { FTSE10o(- } \\
\text { 1) }\end{array}$} & \multirow{5}{*}{-0.04158} & & $\mathrm{C} 6$ & 0.12054 & \\
\hline \multirow{4}{*}{$\begin{array}{l}\text { United } \\
\text { Kingdom }\end{array}$} & & & \multirow{4}{*}{0.0103} & $\mathrm{C}_{3}$ & -0.27981 & \multirow{4}{*}{0.000} \\
\hline & & & & $\mathrm{C}_{4}$ & 0.117176 & \\
\hline & & & & $\mathrm{C}_{5}$ & -0.12239 & \\
\hline & & & & $\mathrm{C} 6$ & 0.979677 & \\
\hline \multirow{4}{*}{ Poland } & \multirow{4}{*}{ WIG $(-1)$} & \multirow{4}{*}{0.179882} & \multirow{4}{*}{0.000} & $\mathrm{C}_{3}$ & -1.87097 & \multirow{4}{*}{0.000} \\
\hline & & & & $\mathrm{C}_{4}$ & 0.348826 & \\
\hline & & & & $\mathrm{C}_{5}$ & -0.10041 & \\
\hline & & & & $\mathrm{C} 6$ & 0.806545 & \\
\hline
\end{tabular}

In the Analysis of $\mathrm{E}$ GARCH results the $\mathrm{C}_{3}$ value explains that there should be other factors become part of the equation or not. In the above table $\mathrm{C}_{3}$ value are significant, which means there are many other factors which effect Islamic and developed market volatility. Further the $\mathrm{C}_{4}$ values of all the stock market returns are significant and their coefficients are Positive which means the stock market shows size effect. Positive coefficient means all the stock market shows high volatility in response of Large size news as compared to low size news. C (5) value In the E GARCH shows the sign effect. The stock markets of Turkey, Indonesia and Oman shows the $\mathrm{C}_{5}$ values are positive and significant which explains that if the good news comes its effect dominant as compare to bad news but the Pakistani, French, Germans, Spanish, Italian, Poland and British Equity markets shows significant and negative values of $\mathrm{C}(5)$ is significant and negative which indicates that the bad news have dominant effect as compared to good news in the stock market. In the results Value of $\mathrm{C}(6)$ is 10.93\%,91.12\%,14.56\%,99.19\%,98.04\%,97.97\%,96.60\%,12.05\%,97.96\% and 80.65\% for Turkey, Pakistan, Indonesia, Oman, France, Germany, Spain, Italy, UK and Poland significant and positive which means that in all the stock markets the previous day volatility persists.

In the Table 6 below explain the which test is best fitted Test from the ARCH family for stock markets to analyses the data. The criteria are where the value of AIC and SC is low the test is best fitted. The results indicate that the Turkish stock returns have-5.10922, -5.10006, Indonesian, stock returns -5.91829, 5.90871, UK stock market returns have -6.43277, -6.42374 low AIC \& SC value when the TARCH is applied. While other countries stock markets have lower AIC and SC value when the EGARCH is applied. So, for the TARCH is best fitted model for Turkish, UK and Indonesian equity market volatility while EGARCH is best for the German, Pakistani, Spanish, Poland, Oman, Italian and French equity markets in this period to find 
out volatility of equity market.

Table 6: Comparison AIC (Akaike info criterion) and SC (Schwarz criterion)

\begin{tabular}{|c|c|c|c|c|c|c|c|}
\hline Country & Test & AIC & $\mathrm{SC}$ & Country & Test & AIC & $\mathrm{SC}$ \\
\hline \multirow{9}{*}{ Turkey } & ARCH & - & - & & ARCH & -5.57097 & -5.56485 \\
\hline & & 4.89407 & 4.88797 & & & & \\
\hline & GARCH & -5.10086 & - & & GARCH & -5.84943 & -5.84177 \\
\hline & & & 5.09323 & & & & \\
\hline & & & & Germany & & & \\
\hline & TARCH & -5.10922 & - & & TARCH & -5.88835 & -5.87916 \\
\hline & & & 5.10006 & & & & \\
\hline & EGARCH & -5.08991 & - & & EGARCH & -5.89022 & -5.8795 \\
\hline & & & 5.08075 & & & & \\
\hline \multirow{5}{*}{ Pakistan } & $\mathrm{ARCH}$ & -5.95297 & -5.9465 & & $\mathrm{ARCH}$ & -5.83099 & -5.81005 \\
\hline & GARCH & -6.10005 & & Spain & GARCH & -5.88717 & -5.861 \\
\hline & TARCH & 611078 & 0.09190 & & TARCH & -582684 & -581066 \\
\hline & $\mathrm{FCARCH}$ & 6 & $-8.1010 /$ & & $\mathrm{E} C \triangle \mathrm{P} C \mathrm{H}$ & $5 \cdot 05004$ & -5800 \\
\hline & & -0.10159 & 6.10785 & & & $-5 \cdot 9399$ & -5.9005 \\
\hline \multirow{7}{*}{ Indonesia } & $\mathrm{ARCH}$ & -5.76854 & $-5 \cdot 76215$ & & $\mathrm{ARCH}$ & $-5 \cdot 56442$ & $-5 \cdot 55833$ \\
\hline & GARCH & - & - & & GARCH & -5.84256 & -5.83494 \\
\hline & & $5 \cdot 90854$ & $5 \cdot 90056$ & & & & \\
\hline & TARCH & -5.91829 & - & Italy & TARCH & -5.87447 & -5.86533 \\
\hline & & & $5 \cdot 90871$ & & & & \\
\hline & EGARCH & -5.90771 & - & & EGARCH & -5.88076 & -5.87162 \\
\hline & & & 5.89972 & & & & \\
\hline \multirow{6}{*}{ Oman } & $\mathrm{ARCH}$ & -11.5797 & -11.5732 & & $\mathrm{ARCH}$ & -6.10072 & -6.09469 \\
\hline & GARCH & -12.7858 & -12.7775 & & GARCH & -6.38983 & -6.3823 \\
\hline & TARCH & -12.7748 & - & United & TARCH & -6.43277 & -6.42374 \\
\hline & & & 12.7649 & Kingdom & & & \\
\hline & EGARCH & -12.7984 & - & & EGARCH & -6.43273 & -6.42219 \\
\hline & & & 12.7886 & & & & \\
\hline \multirow{7}{*}{ France } & $\mathrm{ARCH}$ & -5.62344 & -5.61733 & & $\mathrm{ARCH}$ & $-5 \cdot 51256$ & -5.49672 \\
\hline & GARCH & -5.8819 & - & & GARCH & -5.53706 & $-5 \cdot 51726$ \\
\hline & & & 5.87434 & & & & \\
\hline & TARCH & -5.93075 & - & Poland & TARCH & -5.54699 & $-5 \cdot 52323$ \\
\hline & & & 5.92159 & & & & \\
\hline & EGARCH & - & - & & EGARCH & $-5 \cdot 55761$ & -5.53385 \\
\hline & & 5.93998 & 5.93081 & & & & \\
\hline
\end{tabular}

\section{Conclusion}

This study concluded that the all the Islamic stock markets shows positive returns as compare to previous day return but the developed stock market shows negative returns as compare to previous day return expect span and Poland equity market. This study further explored that the Pakistan stock market shows $44.36 \%$ high volatility and Turkish stock market shows 0.0.3\% low volatility as compare to previous day return among the Islamic equity markets. While the UK equity market explains $40.76 \%$ higher volatile 
and Spanish equity market explains $8.91 \%$ lower volatile as compare to previous day returns. The study explored that in all the stock markets the previous day volatility transfers in the next day volatility. The EGarch Test in this study indicated that there are many other factors are persisting which effect the stock market volatility which should be the part of the equation. So, study motivate to the researchers and market players to find out other factors which effect stock market volatility. The study further investigated that the all the stock markets volatile per the size of the news. So, the investors whose investing in these equity markets should be aware that big news may affect the stock market returns largely either positively or negatively the wealth. Finally, this study concluded that in all the Islamic equity markets except Pakistan good news effect dominantly as compare to bad news. While in all the developed equity markets the bad news, effect is dominant as compare to good news. Investors should focus on country expected economic, political and social news etc. which can affect the stock market returns positively or negatively. This study also helps to researchers and investors that which model of ARCH family is best fitted in the analysis of different equity markets. This study assists the all type of investors including Risk Averse, Risk Indifference, Risk seekers, individual or institutional investors and portfolio managers in understanding the behavior of Islamic and developed equity markets behavior.

\section{Reference:}

Albaity,M. S. (2011). Impact of the Monetary Policy Instruments on Islamic Stock Market Index Return. Economics open assasment E Journal., 90-99

Aksoy, M., \& Akin, F. (2011). Cointegration of MENA Stock Markets: Turkey, Egypt and Israel.International Research Journal of Finance and Economics.,1-14

Azizullah and Abbas (2012) Empiricalinvestigation of the Relationship Between Exchange Rate Movements And Stock Market Volatility.Pakistan Business Review,34-45

Chukwuogor and Feridun (2007). Conventional and Islamic Indices IndonesiaComparisonVolatility, and The Determinants. Finance \& Development.78-90

Relu and Basupria (2001) Stock Market Volatility Transmission in Malaysia:Islamic Versus Conventional Stock Market. J.KAU: Islamic Economic, 101,110

Teresiene, D., Aarma, A. and Dubauskas, G., (2008). "Relationship between stock market and macroeconomic volatility." Transformation in Business and Economics. 7(2), 102-114

Wongbangpo, P., \& Sharma, S. C. (2002). "Stock market and macroeconomic fundamental dynamic interactions: ASEAN-5 countries.” Journal of Asian Economics, 13(1), 27-51.

Yusof, R. M., \& Majid, M. S. A. (2007). "Stock market volatility transmission in Malaysia: Islamic versus conventional stock market.” Journal of King Abdulaziz University: Islamic Economic, 20(2), 1735 .

Yusof, R. M., \& Majid, M. S. A. (2009). "Long-run relationship between Islamic stock returns and macroeconomic variables: An application of the autoregressive distributed lag model.” Humanomics, 25(2), 127-141.

Zaman, Imran and Wasif (2004). The Co-Movement of Stock Markets in East AsiaDid the Asian Financial Crisis Really Strengthen Stock Market Integration. European Journal of Finance 10(2), 139-148.

Zaher, T.S. \& M.K. Hassan (2001). "A comparative literature survey of Islamic finance and banking." Financial Markets, Institutions \& Instruments 10(4), 155-199 